\title{
Traduire
}

Une eutre perspective sur $r$ tatadciction

Revue française de la traduction

$230 \mid 2014$

À la croisée du texte et de l'image

\section{Ouvrage : La Cigarette et le Néant, Horace Engdahl}

Serge Safran publie le premier ouvrage traduit en français de l'écrivain suédois

\section{Andrea Genovese}

\section{(2) OpenEdition}

\section{Journals}

Édition électronique

URL : http://journals.openedition.org/traduire/643

DOI : $10.4000 /$ traduire.643

ISSN : 2272-9992

Éditeur

Société française des traducteurs

Édition imprimée

Date de publication : 15 juin 2014

Pagination : 127

ISSN : 0395-773X

\section{Référence électronique}

Andrea Genovese, « Ouvrage : La Cigarette et le Néant, Horace Engdahl », Traduire [En ligne], 230 | 2014,

mis en ligne le 23 novembre 2015, consulté le 25 septembre 2020. URL : http://

journals.openedition.org/traduire/643; DOI : https://doi.org/10.4000/traduire.643 


\title{
Ouvrage : La Cigarette et le Néant, Horace Engdahl
}

\author{
Serge Safran publie le premier ouvrage traduit en français de l'écrivain \\ suédois
}

Andrea Genovese

\section{RÉFÉRENCE}

La Cigarette et le Néant, Horace Engdahl, Serge Safran éditeur, 2014.

\section{NOTE DE L'ÉDITEUR}

Compte rendu extrait de Belvédère $\mathrm{n}^{\circ} 27$, janvier 2014, p.9.

1 Il y a une page célèbre de La coscienza di Zeno, où Italo Svevo disserte sur son addiction à la cigarette. Le propos «Puisque fumer me fait mal, je ne fumerai plus mais avant je veux le faire pour la dernière fois ", jamais observé, est devenu paradigmatique de l'ennui et de l'angoisse existentiels. Écrivain et critique, membre de l'Académie suédoise, Horace Engdahl ne cite jamais l'écrivain italien, mais en cite des dizaines d'autres, classiques et modernes, de son pays et d'Europe, dans une sorte de journal intime truffé d'aphorismes et de courts textes, La Cigarette et le Néant, qui vient de paraître chez l'éditeur Serge Safran. Justement, en voilà un extrait :

«La perspective de la fin du monde serait parfaitement supportable, si seulement on pouvait s'en griller une après ». On comprend d'emblée que ce livre est une de ces œuvres rares, qui ne déplairaient ni à Montaigne ni à Sterne, où l'écriture porte un regard désenchanté sur l'homme et son indéchiffrable destin, sur l'histoire, la littérature et les frontières mystérieuses qui séparent "le lisible et le scriptible » (Barthes cité), les combats ou les accommodements entre le Moi (valéryen) et le monde. Une finesse et une rigueur enlevées, exigeantes, mais pas de tout repos: "Rien de pire qu'un public qui, bêtement, rit aux éclats. Un auditoire terrifié, c'est déjà mieux ", ou encore "Le rôle des intellectuels dans l'Histoire est d'intégrer le 
mal dans un système qui l'affranchirait des considérations morales. On ne saurait persister dans l'inhumain sans théorie à l'appui. ».

2 La traduction de cet ouvrage de 158 pages, le premier paru en France d'Horace Engdahl, a été réalisée par une équipe de traducteurs (quinze !) sous la direction d'Elena Balzamo - spécialiste de littérature scandinave que son nom italien n'a pas empêchée de naître à Moscou et de vivre à Paris - dans le cadre d'un séminaire de traduction à l'Institut suédois de Paris. Tout un équipage pour lancer un bateau, c'est sûrement un bon signe. 